\title{
クアッドロータヘリの重心移動による操作 一ヒューマノイドロボットによる操作一
}

\author{
Quad Rotor Control by Centroid shifting \\ -A Humanoid Robot Rides on a Quad Rotor Helicopter- \\ 学 久納 慎吾 (徳島大) ○正 三輪 昌史（徳島大）
正 二井見 博文 (産技短大)
}

Shingo KUNOU, The University of Tokushima

Masafumi Miwa, The University of Tokushima, miw@tokushima-u.ac.jp

Hirofumi NIIMI, College of Industrial Technology

\begin{abstract}
In this study, we set a humanoid robot on the center of experimental quad-rotor helicopter (QRH). When the humanoid tilts, this motion shifts the center of gravity, and it causes the attitude change of the quad rotor helicopter. Then attitude control system generates counter torque to cancel the tilt angle. As the result, small inclination exists when counter torque balances to load torque. This small inclination generates moving thrust, and QRH starts to slide. This result means that we can control QRH with external independent devices attached on it.
\end{abstract}

Key Words: Quad rotor helicopter, PD control, Attitude control, Center of gravity, External control

\section{1. 緒言}

$\mathrm{R} / \mathrm{C}$ ヘリコプタは大型の無人航空機(UAV)と比較した場合、 墜落時のリスクが低い点、運用に必要なコストを抑える事が 出来る点、離着陸に必要な面積を減らす事が出来る点で優れ ており、一般的な空撮だけでなく高圧線の架線作業や農薬散 布作業にも用いられている。しかし、R/Cへリコプタを用いた 架線作業や農薬散布などの運搬作業は操作技能の習得が不可 欠であり、R/Cヘリコプタが普及し運搬作業に広く用いられる には操縦者の技量に負う作業を簡便化し、より簡単に操作す る方法が必要になる。そこで本研究では操作をより簡単に行 うため、独立した姿勢制御系を持つ四発ロータヘリコプタ $(\mathrm{QRH})$ の制御系に外部入力を加えて制御する方法を提案する。

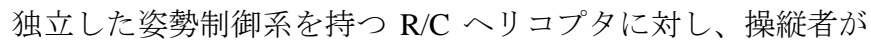
機体に対して外力を加えることで位置制御を行えば、直感的 に機体の操作を行うことができ、操縦技術のない人でも操作 が可能になる。また QRH はロータの推力差を利用し任意の方 向に機体を傾斜させ推力の水平分力を利用して移動を行う。 このことから QRHに外力を加え機体を傾斜させることで移動 を行う事が可能である[1]。そこで本研究では独立した姿勢制 御系を持つ $\mathrm{QRH}$ の制御系に外部入力を加えて制御することを 目的とする。今回、姿勢制御に PD 系を持つ QRH に対し重心 位置を操作することで機体の移動を行う実験を実施した。

\section{2. 重心移動時の QRH の挙動}

重心が変化していないときの、QRH の傾斜 $\theta$ に対する $\mathrm{P}$ 制 御の応答の様子を図 1 に示す。図中の丸は機体の重心を表し、 図中の矢印はロータが回転することにより生じる推力を表す。 また、図中上部に外部入力を加えるための装置を四角で示す。 この装置を駆動させることにより、機体の重心位置が変化す る。まず、機体が水平のとき、左右に生じる推力が

$$
F_{L}=F_{R}=F
$$

となる。ここで、 $\mathrm{F}$ は機体が水平の時のロータ出力である。左 右に生じる推力の大きさ及び重心からの距離が等しい場合、 推力に起因するトルク $T_{L}$ 及び $T_{R}$ の合計は

$$
T_{L}+T_{R}=0
$$

となる。次に $\mathrm{QRH}$ の姿勢が $\theta$ に変化すると、機体の $\mathrm{P}$ 制御が 働き、図 1 の様に推力が変化することで $T_{R}>T_{L}$ となり、 $T_{R}-T_{L}$ のトルクで水平に戻そうとする。

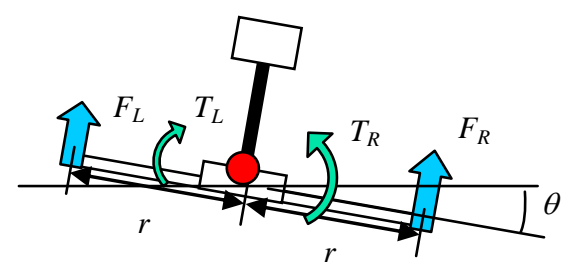

Fig. 1 Schematic view of QRH seen from Pitch shaft orientations

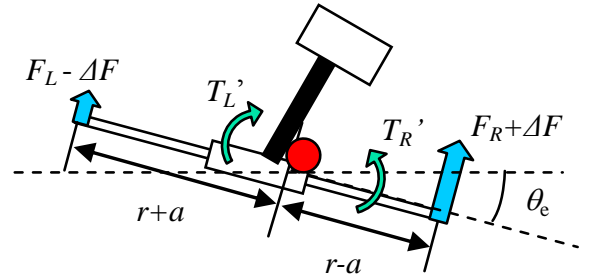

Fig. 2 Center of gravity Shift and Thrust Change

このときに発生する操作量は次式となる。

$$
K_{p} \theta=2 \Delta F r
$$

ここで、 $\Delta F$ は左右のロータに作用寸る推力変化量、 $r$ は機体 中心からロータ軸までの長さ、 $K_{p}$ は $\mathrm{P}$ 制御のゲインである。 また、ロータ推力がそれぞれ

$$
F_{L}=F-\Delta F, F_{R}=F+\Delta F
$$

となる。次に重心位置が変化したときの $\mathrm{QRH}$ の傾斜角 $\theta$ での 様子を図 2 に示す。機体の重心の変化により、推力に起因す る重心まわりのトルクはそれぞれ $T_{L}{ }^{\prime}=-F_{L}(r+a), T_{R}{ }^{\prime}=F_{R}(r-a)$ となり、この合計が穖体に加わるトルクであり、

$$
T_{\text {total }}=2 \Delta F r-2 F a=K_{p} \theta-2 F a
$$

となる。式(3)より、 $\theta$ が

$$
\theta=\theta_{e}=2 F a / K_{p}
$$

をみたすとき $T_{\text {total }}=0$ となり、図 $\mathrm{QRH} 2$ の様に静止角度 $\square_{e}$ を 維持したまま機体が水平に移動することになる。 $\theta_{e}$ は QRH が $\mathrm{P}$ 制御を行う時に生じる定常偏差であり、 $a$ の変化に比例する。 このことから機体の重心を変化させることで $\mathrm{QRH} の$ 傾斜を制 御できる。 


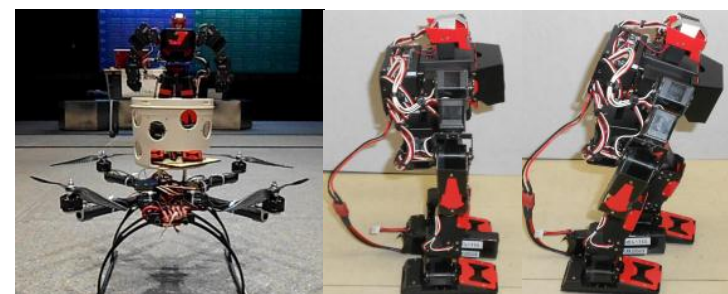

(a) Test QRH

(b) Forward tilt posture

Fig. 3 Test QRH With Humanoid Robot

Table 1 Specification of Test QRH

\begin{tabular}{|c|c|}
\hline Size & $600 \times 700 \times 700(\mathrm{~mm})$ \\
\hline Rotor axis distance & $520 \mathrm{~mm}$ \\
\hline Rotor diameter & $330 \mathrm{~mm}$ \\
\hline Weight & $2.51 \mathrm{~kg}$ \\
\hline
\end{tabular}

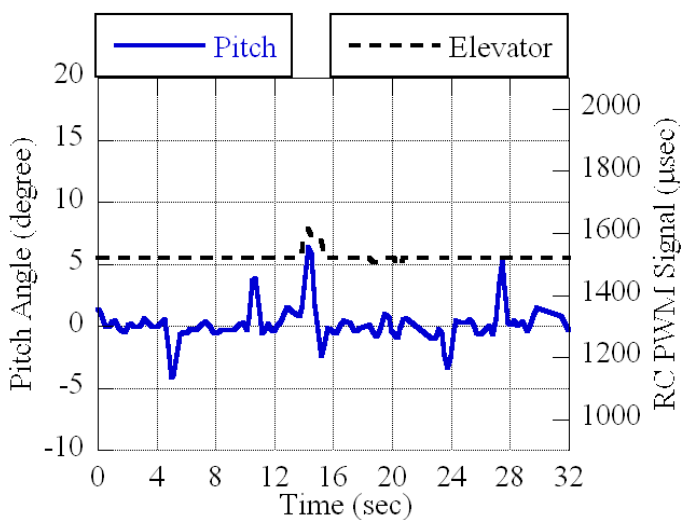

(a) Pitch axis

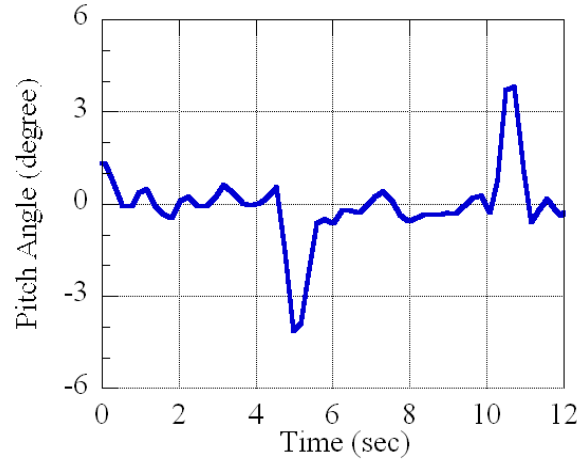

(b) Pitch axis (enlarged view)

Fig. 4 Attitude Change of Test QRH with Arm Tilting

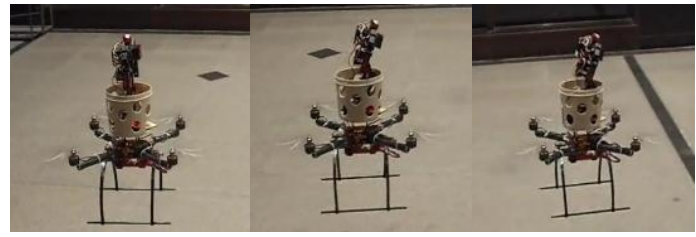

Fig. 5 Flight test

Table2 QRH Attitude

\begin{tabular}{|c|c|c|}
\hline \multirow{2}{*}{ Control period (sec) } & \multicolumn{2}{|c|}{ Average attitude angle (degree) } \\
\cline { 2 - 3 } & Roll & Pitch \\
\hline $4-11$ & -0.7 & -1.7 \\
\hline $23-29$ & -0.5 & -2.1 \\
\hline
\end{tabular}

\section{3. 実験装置及び実験方法}

\section{1 実験装置}

実験に使用した QRH (enRoute : Zion Pro 520 Quadcopter ) と ヒューマノイドロボットの外観を図 3(a)に示す。実験機は QRH の中央部にヒューマノイドロボット(JO-zero:姫路ソフト ワークス)を搭載した。実験機の仕様を表 1 に示す。ヒューマ ノイドロボットは機体の重心を変化させるための装置である QRH の制御系は ArduinoPilotMega2.0 (3DRobotics、以下 APM) を用い制御用ソフトに arducoptor 2.9 (DIY Drones)を使用し、姿 勢制御に PD 制御を採用した。 $\mathrm{QRH}$ の操作は R/C 送信機 (T12FGH : 双葉電子工業)で行い、ヒューマノイドロボットの 操作は赤外線リモコン(RM-A205 : victor)で行った。また、APM は XBeeProZB (Digi international)を通し PCにフライトログを 記録している。

\section{2 実験方法}

実験では実験機の離着陸を $\mathrm{R} / \mathrm{C}$ 送信機からマニュアル操縦 で行った。機体の姿勢制御は APM の PD 制御にまかせ、水平 維持を行った。図 3(b)の様に実験機にはヒューマノイドロボッ 卜を前傾することで外力を与えた。ヒューマノイドロボット の傾斜はあらかじめモーションを設定しておき、赤外線リモ コンでコマンド操作を行った。

\section{4. 実験結果}

図 4 および表 2 に機体姿勢に関する実験結果を示す。この 実験ではPitch についての傾斜実験を行った。図中の 0 秒から 4 秒まではマニュアル操作にて機体を離陸させ、実験開始位置 まで移動させた時の傾斜の変化である。その後機体が水平に なった 4 秒においてヒューマノイドロボットの操作コマンド を入力し、8 秒間ヒューマノイドロボットを傾けた。このとき の機体が $1.7^{\circ}$ 程度傾斜している。12 秒から 20 秒まではマニ ユアル操作で機体の位置を戻し、23 秒から再度ロボットアー ムを傾けた。なお、ヒューマノイドロボットを操作している 時は R/C コントローラの入力はニュートラルとした。この時、 機体は $2.1^{\circ}$ 程度傾斜した。図中より機体が傾斜していること が確認できる。このとき機体が移動した。以上の実験結果か ら、ヒューマノイドロボットを QRH に搭載し、重心位置を操 作することで移動制御を行う方法は有効であることが判る。

\section{5. 結論}

本研究では直感的に QRH を操作する方法として、独立した 姿勢制御系を持つ $\mathrm{QRH}$ の制御系に外部入力を加えて制御する 方法を提案した。姿勢制御に PD 制御を採用した QRH に対し ロボットを駆動し外力を加え、機体の重心を操作することで 機体の方位制御を行った。

\section{文 献}

[1] Masafumi Miwa, Shingo Kunou, Shinji Uemura, Akitaka Imamura and Hirofumi Niimi: Attitude Control of Quad-Rotor Helicopter with Mass Balance, Proc, of the ISEM12 in Taipei, Taipei, Nov. 2012. 